\title{
Pengaruh Status Sosial Ekonomi dan Lingkungan Kampus Terhadap IPK Mahasiswa
}

\author{
Dedi Setiawan ${ }^{1}$, Hendra Dani Saputra ${ }^{1 *}$, M. Nasir ${ }^{1}$ \\ ${ }^{11}$ Jurusan Teknik Otomotif, Fakultas Teknik, Universitas Negeri Padang \\ ${ }^{*}$ Corresponding author, e-mail: hendradani@ft.unp.ac.id
}

\begin{abstract}
Abstrak - Penelitian bertujuan untuk melihat pengaruh lingkungan kampus terhadap IPK, pengaruh status sosial ekonomi terhadap IPK serta pengaruh lingkungan kampus dan status sosial ekonomi terhadap IPK . Penelitian ini merupakan penelitian deskriptif kuantitatif assosiatif. Populasi dalam penelitian ini adalah mahasiswa S1 dan D3 Teknik Otomotif Fakultas Teknik Universitas Negeri Padang tahun masuk 2016. Total populasi sebanyak 137 mahasiswa. Sampel yang diambil sebanyak 103 orang. Teknik analisis yang digunakan adalah analisis regresi sederhana dan regresi berganda. Hasil penelitian menunjukkan bahwa 1) status sosial ekonomi tidak berpengaruh signifikan terhadap IPK mahasiswa Jurusan Teknik Otomotif Fakultas Teknik UNP, 2) lingkungan kampus tidak berpengaruh signifikan terhadap IPK mahasiswa Jurusan Teknik Otomotif Fakultas Teknik UNP dan 3) status sosial ekonomi dan lingkungan kampus tidak berpengaruh signifikan terhadap IPK mahasiswa Jurusan Teknik Otomotif Fakultas Teknik UNP.
\end{abstract}

Kata Kunci : Status Sosial Ekonomi, Lingkungan Kampus, IPK, Mahasiswa

\begin{abstract}
This research aimeds to see the effect of the campus environment on GPA, the effect of socio-economic status on the GPA and the effect of the campus environment and socio-economic status simultaneously on the GPA. This research was a descriptive quantitative associative of study. The population in this study were S1 and D3 students in Automotive Engineering, Faculty of Engineering Universitas Negeri Padang in 2016. The total population was 137 students. Samples taken were 103 people. The analysis technique used was simple regression analysis and multiple regression. The results showed that 1) socioeconomic status did not significantly influence the GPA of the students of Automotive Engineering Department, Faculty of Engineering UNP, 2) the campus environment had no significant effect on the GPA of the students of the Automotive Engineering Department, Faculty of Engineering UNP and 3) the socio-economic status and campus environment simultaneously had no significant effect towards the GPA of the Automotive Engineering Department, Faculty of Engineering, UNP.
\end{abstract}

Keywords : Socio-Economic Status, Campus Environment, GPA, Students

This is an open access article distributed under the Creative Commons 4.0 Attribution License

\section{Pendahuluan}

Hakikat pendidikan adalah proses pembentukan menjadi manusia seutuhnya. Pendidikan Nasional Indonesia memberikan gambaran bagaimana maksud dan tujuan dari pendidikan itu sendiri. Melalui UU Pendidikan Nasional No. 20 Tahun 2003 pemerintah memberikan gambaran pendidikan merupakan proses untuk mencerdaskan kehidupan bangsa yang memilki iman dan taqwa kepada Tuhan yang Maha Esa, berakhlak mulia, sehat, berilmu, cakap, kreatif, demokratis dan bertanggung jawab.[1] Proses pembentukan manusia didapatkan melalui proses belajar. Hamalik, O. (2008), menyatakan Belajar merupakan perubahan tingkah laku yang relatif mantap berkat latihan dan pengalaman.[2]

Universitas Negeri Padang merupakan salah satu perguruan tinggi yang memprioritaskan mahasiswa lulusannya agar kompeten dalam dunia pendidikan dan siap terjun ke dunia kerja yang berhubungan dengan dunia pendidikan. Persaingan dunia kerja dalam bidang pendidikan tidaklah semudah yang dibayangkan. Selain memiliki kemampuan yang sesuai dengan permintaan dunia 
kerja, sebahagian dunia usaha juga menentapkan indeks prestasi yang akan diterima perusahan. Meskipun dalam mendapatkan pekerjaan nantinya mahasiswa ini akan diuji kembali, tetapi prestasi yang mereka peroleh selama di bangku perkuliahan turut menentukan kesempatan mereka.

Banyak faktor yang mengakibatkan rendahnya hasil Indeks Prestasi mahasiswa khususnya mahasiswa otomotif Fakultas Teknik UNP. Indeks prestasi kumulatif (IPK) mahasiswa sebagai gambaran prestasi belajarnya dipengaruhi oleh dua faktor : faktor internal dan eksternal. Faktor internal dapat berupa motivasi, bakat dll. Pengaruh faktor internal ini dapat dilihat pada hasil penelitian Saputra, H. D. (2018), yang menunjukkan pengaruh motivasi terhadap hasil belajar yang memiliki hubungan yang positif dan signifikan.[3] Pada penelitian yang dilakukan berfokus pada faktor ekternal yang mempengaruhi Indek Prestasi Kumulatif (IPK) mahasiswa. faktor ekternal yang akan diteliti yaitu sosio ekonomi dan lingkungan kampus.

Status sosial ekonomi merupakan posisi yang didapatkan baik secara individual maupun kelompok. Posisi tersebut dapat berupa jabatan, penghasilan, pemilikan barang dan keikutsertaan seseorang dalam sebuah organisasi.. Kecendrungan masyarakat adalah menilai bahwa keberhasilan mahasiswa ditentukan oleh latar belakang sosial ekonomi keluarga, seperti pendidikan dan pendapatan orangtua.

Faktor eksternal lain yang diduga mempengaruhi Indeks Prestasi mahasiswa yaitu faktor lingkungan kampus. Di lingkungan kampus mahasiswa melakukan berbagai aktifitas dan berkarya dengan berbagai macam sumber-sumber, media-media, dan metode-metode yang ada pada lingkungan kampus untuk meningkatkan kompetensi dan Indeks Prestasi yang ingin mahasiswa capai. Saputra, H. D. (2018), dalam penelitiannya menyatakan media pembelajaran yang efektif akan dapat meningkatakan efektivitas dari pembelajaran.[4] Sehingga dengan efektivitas dan efisiennya kegiatan yang dilakukan oleh mahasiswa di lingkungan kampus, akan memberikan hasil berupa IPK yang bagus dan tinggi pula.

\section{Tinjauan Pustaka}

Tinjauan pustaka akan memberikan penjelasan perihal teori teori tentang; belajar, ukuran pretasi belajar, status sosial ekonomi dan lingkungan kampus.

\section{A. Prestasi Belajar}

Prestasi merupakan suatu kegiatan yang telah dikerjakan sehingga menghasilkan sesuatu untuk diciptakan kembali secara individual maupun kelompok. Sudjana, N. (2010). Secara garis besar mengelompokkan prestasi belajar atas tiga ranah, yaitu:

1. Kognitif, yang berhubungan dengan intelektual terdapat enam aspek, yaitu pengetahuan (ingatan), pemahaman, aplikasi, analisis, sintesis dan evaluasi.

2. Afektif, merupakan sikap yang terdiri dari lima aspek, yaitu penerimaan, jawaban atau reaksi, penilaian, organisasi, dan internalisasi.

3. Psikomotor, merupakan keterampilan dan kemampuan bertindak.[5]

\section{B. Ukuran Prestasi Belajar}

Prestasi belajar mahasiswa di Perguruan Tinggi dapat dilihat dari indeks prestasi (IP) mahasiswa tersebut. Nilai suatu mata kuliah dapat dinyatakan dengan nilai mutu (NM), tabel di bawah merupakan gambaran nilai mutu.

Tabel 1. Nilai Mutu Prestasi Belajar Mahasiswa

\begin{tabular}{|c|c|c|c|}
\hline $\begin{array}{c}\text { Nilai } \\
\text { Angka } \\
\text { (NA) }\end{array}$ & $\begin{array}{c}\text { Nilai } \\
\text { Mutu } \\
\text { (NM) }\end{array}$ & $\begin{array}{c}\text { Angka } \\
\text { Mutu } \\
\text { (AM) }\end{array}$ & $\begin{array}{c}\text { SebutanMutu } \\
\text { (SM) }\end{array}$ \\
\hline $85-100$ & $\mathrm{~A}$ & 4,00 & Dengan Pujian \\
$80-84$ & $\mathrm{~A}-$ & 3,6 & Sangat Baik Sekali \\
$75-79$ & $\mathrm{~B}+$ & 3,3 & Baik Sekali \\
$70-74$ & $\mathrm{~B}$ & 3,0 & Baik \\
$65-69$ & $\mathrm{~B}-$ & 2,6 & Cukup Baik \\
$60-64$ & $\mathrm{C}+$ & 2,3 & Lebih Dari Cukup \\
$55-59$ & $\mathrm{C}$ & 2,0 & Cukup \\
$50-54$ & $\mathrm{C}-$ & 1,6 & Kurang Cukup \\
$40-49$ & $\mathrm{D}$ & 1,0 & Kurang \\
$\leq 39$ & $\mathrm{E}$ & 0,0 & Gagal \\
& $\mathrm{T}$ & - & Tertunda \\
\hline
\end{tabular}

Sumber: UNP.P.K. (2017).[6]

\section{Faktor-Faktor yang Mempengaruhi Prestasi Belajar}

Hasil belajar mahasiswa dipengaruhi oleh faktor internal mahasiswa dan faktor eksternal mahasiswa. Faktor internal merupakan faktor yang bersumber dari dalam diri mahasiswa. Selanjutnya faktor eksternal, yaitu faktor-faktor yang bersumber dari luar diri mahasiswa, seperti lingkungan non sosial (lingkungan non-sosial baik fisik maupun non-fisik) seperti: sarana dan 
prasarana pendukung yang digunakan mahasiswa. Sejalan dengan itu Dalyono. (2012), menjelaskan dua faktor yang mempengaruhi prestasi belajar yaitu faktor intern dan faktor ekstern.[7] Faktor intern antara lain faktor jasmani, faktor psikologis kemudian faktor kelelahan. Faktor ekstern berupa lingkungan keluarga, lingkungan sekolah, dan faktor masyarakat.

\section{Status Sosial Ekonomi}

Status sosial ekonomi seseorang berpengaruh dalam berbagai bidang seperti kehidupan bermasyarakat, pekerjaan bahkan pendidikan. Indikator faktor eksternal yang mempengaruhi belajar seseorang dapat berupa status sosial ekonomi mahasiswa. Sugihartono, d. (2015) berpendapat, status sosial ekonomi orang tua meliputi tingkat pendidikan orang tua, pekerjaan orang tua, penghasilan orang tua.[8] Sejalan dengan itu, Soekanto, S. (2007) menyatakan bahwa anggota masyarakat dapat dibagi menjadi berbagai lapisan sosial. Status sosial ekonomi dapat diuraikan menjadi : pekerjaan, pendidikan pendapatan,jumlah tanggungan orang tua, kepemilikan dan jenis tempat tinggal.[9]

Pendidikan merupakan salah satu kebutuhan bagi mahasiswa. Jenis penyelenggaraan pendidikan terbagi 3 yaitu; satu, pendidikan formal yaitu pendidikan yang dilakukan diwilayah resmi seperti sekolah, kampus yang mempunyai jenjang, persyaratan, dan aturan yang tegas. Dua pendidikan informal merupakan pendidikan yang diterima melalui keluarga atau masyarakat dan hal ini lebih berdasaran pengalaman. Tiga, pendidikan non formal merupakan jenis penyelenggaraan pendidikan yang dilakukan diluar sekolah. Penyelenggaraanya dilakukan secara teratur namun tidak seperti di sekolah formal.

Kecenderungan masyarakat adalah menilai bahwa keberhasilan mahasiswa ditentukan oleh latar belakang sosial ekonomi keluarga, seperti pendidikan dan pendapatan orangtua. Pendidikan yang dimiliki oleh orangtua akan mencerminkan kemampuan belajar yang baik bagi mahasiswa, Dengan kata lain semakin tinggi pendidikan dan pendapatan orang tua dapat memberikan gambaran yang positif terhadap kemampuan mahasiswa dalam belajar

\section{E. Lingkungan Kampus}

Lingkungan kampus merupakan tempat dimana mahasiswa melakukan proses perkuliahan. Lingkungan kampus adalah segala sesuatu yang ada di sekitar mahasiswa yang berpengaruh terhadap proses perkuliahan. Letak kampus, metode, kurikulum, hubungan dengan warga kampus tentu akan memperngaruhi proses perkulihan mahasiswa. Slameto. (2010) menyatakan faktor sekolah/kampus yang berpengaruh terhadap hasil belajar antara lain 1) metode mengajar, 2) relasi dosen dengan mahasiswa, 3) relasi mahasiswa dengan mahasiswa, 4) disiplin sekolah dan 5) fasilitas sekolah.[10] Sejalan dengan pendapat Slameto di atas Indeks Prestasi mahasiswa dapat dipengaruhi oleh faktor lingkungan kampus dalam hal ini disebutkan sebagai fasilitas sekolah/kampus.

Lingkungan kampus juga berkaitan juga dengan fasilitas yang ada di Universitas Negeri Padang masih belum memadai. Hal ini akan menyebabkan proses perkuliahan tidak terlaksana dengan optimal. Yusuf. (2011) berpendapat lingkungan sekolah merupakan wadah pelaksanaan program bimbingan, pelajaran dan pelatihan yang bertujuan membantu siswa agar mampu mengembangkan potensinya, baik menyangkut aspek moral, spiritual, intelektual, emosional maupun sosial.[11]

\section{METOde Penelitian}

Metode penelitian memberikan gambaran tentang jenis dan teknik analasis data yang akan dilakukan

\section{A. Jenis Penelitian}

Penelitian dikategorikan sebagai penelitian deskriptif kuantitatif assosiatif. Sugiyono. (2014) menyatakan bahwa, deskriptif kuantitatif asosiatif adalah penelitian yang menguji ada atau tidaknya hubungan atau pengaruh antara satu variabel dengan variabel lainnya.[12]

Populasi dalam penelitian ini adalah mahasiswa jurusan teknik otomotif Fakultas Teknik Universitas Negeri Padang S1 sebanyak 81 mahasiswa dan D3 sebanyak 56 mahasiswa tahun masuk 2016. Total populasi sebanyak 137 mahasiswa. Sampel penelitian sebanyak 103 orang terdiri dari mahasiswa S1 dan D3. Sampel diambil berdasarkan aturan Arikunto.S (2010) menyatakan pengambilan sampel dalam penelitian ini dilakukan secara random sampling. Dalam penelitian ini ukuran sampel ditentukan dengan menggunakan rumus Slovin.[13]

Keterangan :

$$
n=\frac{N}{1+N e^{2}}
$$

$\mathrm{n}$ = ukuran sampel

$\mathrm{N}=$ ukuran populasi 
$\mathrm{e}=$ kelonggaran ketidaktelitian karena kesalahan pengambilan sampel yang dapat ditolerir

Teknik pengumpulan data berupa pemberian kuisioner atau angket. Angket digunakan untuk memperoleh data tentang pengaruh status sosial ekonomi dan lingkungan kampus terhadap IPK mahasiswa jurusan teknik otomotif.

\section{B. Teknik Analisis Data}

Data penelitian dianalisis dengan menggunakan teknik korelasional regresi linier sederhana untuk mengetahui pengaruh status sosial ekonomi mahasiswa dan lingkungan kampus terhadap indeks prestasi mahasiswa jurusan Teknik Otomotif.

\section{Uji Prasyarat Analisis}

\section{Uji Normalitas}

Uji normalitas dilakukan untuk mengetahui apakah sebaran data berasal dari populasi berdistribusi normal atau tidak. Uji normalitas dilakukan dengan menggunakan teknik uji Kolmogorov-Smirnov.

\section{Uji Liniearitas}

Uji linieritas digunakan untuk mengetahui apakah hubungan antara variabel bebas dengan variabel terikat berbentuk garis lurus atau tidak. Uji linearitas dengan mencari nilai Deviation from Linearity dan melihat nilai Sig pada tabel test statistik terpadu

\section{Pengujian Hipotesis Statistik}

Untuk melihat pengaruh antar variabel bebas dengan variabel terikat maka digunakan analisis regresi berganda.

\section{HaSil dan PEMbaAhasan}

Setelah dilkukan pengumpulan data. Kemudian dilakukan penyusunan data ke dalam bentuk suatu distribusi frekuensi. Tahapan penyusunan distribusi frekuensi dilakukan melalui tahapan berikut ini;

1. Menentukan jangkauan (range) dari data. Jangkauan $=$ data terbesar - data terkecil.

2. Menentukan banyaknya kelas (k). Banyaknya kelas ditentukan dengan rumus sturgess $\mathrm{K}=1+$ $3.3 \log \mathrm{n} ; \mathrm{k}$ (Keterangan: $\mathrm{k}=$ banyaknya kelas, $\mathrm{n}=$ banyaknya data)

3. Menentukan panjang interval kelas. Panjang interval kelas (i) = Jumlah Kelas (k)/ Jangkauan (R). Interval kelas adalah selang yang memisahkan kelas yang satu dengan kelas yang lain.

4. Menentukan batas bawah kelas pertama. Tepi bawah kelas pertama biasanya dipilih dari data terkecil atau data yang berasal dari pelebaran jangkauan (data yang lebih kecil dari data data terkecil) dan selisihnya harus kurang dari panjang interval kelasnya.

5. Menuliskan frekuensi kelas didalam kolom turus atau tally (sistem turus) sesuai banyaknya data.

Data yang telah disusun ke dalam suatu tabel distribusi frekuensi, kemudian digambarkan melalui grafik histogram.

\section{A. Indeks Prestasi Kumulatif Mahasiswa Jurusan Teknik Otomotif Fakultas Teknik UNP}

Indeks prestasi kumulatif mahasiswa Jurusan Teknik Otomotif Fakultas Teknik UNP tahun masuk 2016 dengan nilai minimum adalah 2,21 dan nilai maksimum 3,70. Hasil pengolahan data diperoleh nilai rata-rata (mean) sebesar 2,98, modus (mode) sebesar 3,01, median sebesar 3,01 dan simpangan baku (standar deviation) sebesar 0,32 . Skor rata-rata, modus dan median ini tidak jauh berbeda dan tidak melebihi satu simpangan baku. Ini berarti bahwa distribusi indeks prestasi kumulatif cenderung normal. Gambaran distribusi frekuensi skor indeks prestasi kumulatif dapat dilihat pada Tabel 2 berikut ini:

Tabel 2. Distribusi Frekuensi Skor Indeks Prestasi Kumulatif

\begin{tabular}{|c|c|c|c|c|}
\hline $\begin{array}{c}\text { Kelas } \\
\text { interval }\end{array}$ & Fo & \% fo & Fk & \% fk \\
\hline $2,21-2,40$ & 3 & 2.91 & 3 & 2.91 \\
\hline $2,41-2,60$ & 12 & 11.65 & 15 & 14.56 \\
\hline $2,61-2,80$ & 14 & 13.59 & 29 & 28.16 \\
\hline $2,81-3,00$ & 21 & 20.39 & 50 & 48.54 \\
\hline $3,01-3,20$ & 30 & 29.13 & 80 & 77.67 \\
\hline $3,21-3,40$ & 13 & 12.62 & 93 & 90.29 \\
\hline $3,41-3,60$ & 8 & 7.77 & 101 & 98.06 \\
\hline $3,61-3,80$ & 2 & 1.94 & 103 & 100.00 \\
\hline Jumlah & 103 & $\mathbf{1 0 0 , 0 0}$ & & \\
\hline
\end{tabular}

Data diatas didapatkan 20,39\% dari skor Indeks Prestasi Kumulatif berada pada kelas interval skor rata-rata, $28,16 \%$ berada di bawah kelas interval skor rata-rata dan $51.36 \%$ berada di atas kelas skor rata-rata. Untuk lebih jelas dapat dilihat pada Gambar 1.

Dari olahan data tersebut disimpulkan bahwa data Indeks Prestasi Kumulatif berdistribusi normal dimana selisih nilai mean, median dan modus tidak melebihi standar deviasi. 


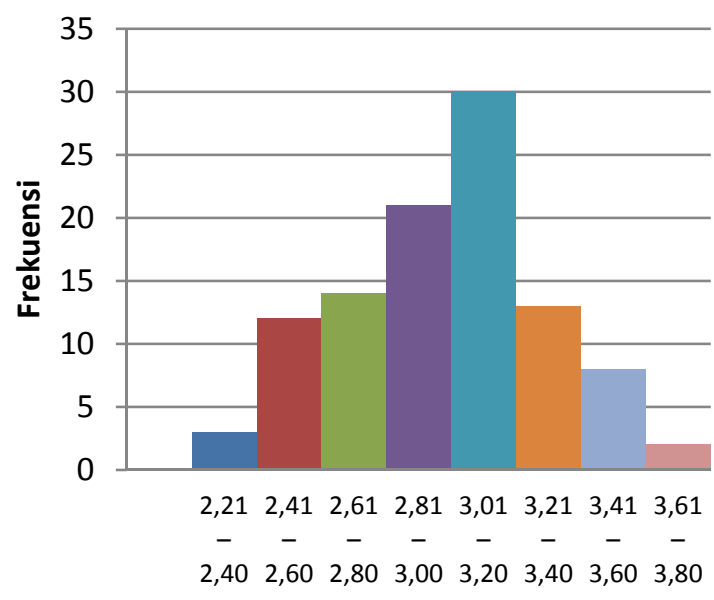

Kelas Interval

Gambar 1 Grafik histogram Indeks Prestasi Kumulatif

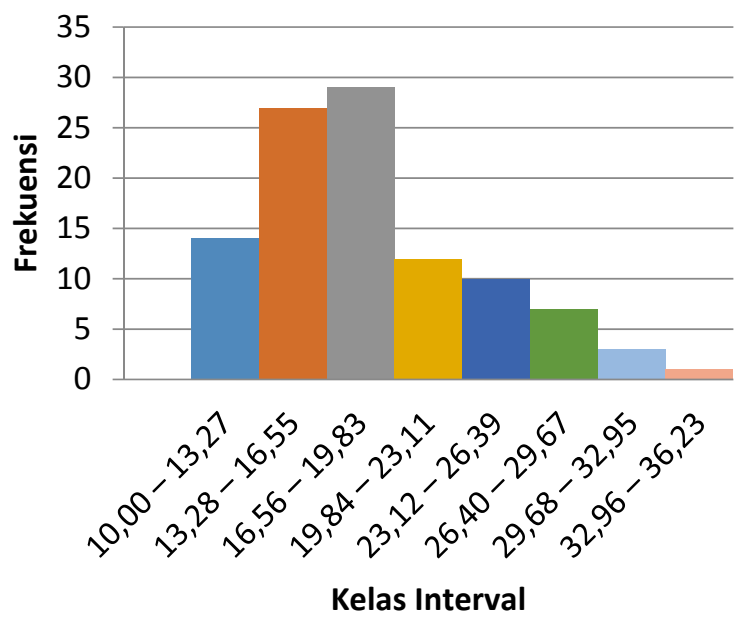

Gambar 2. Grafik histogram Status Sosial Ekonomi

\section{B. Pengaruh Status Sosial Ekonomi Mahasiswa Jurusan Teknik Otomotif Fakultas Teknik UNP}

Dari hasil pengolahan data diperoleh skor ratarata (mean) sebesar 18.67, modus (mode) sebesar 15, median sebesar 18, dan simpangan baku (standar deviation) sebesar 5,30 harga skor ratarata, modus dan median tidak jauh berbeda dan tidak melebih satu simpangan baku, ini berarti bahwa distribusi status sosial ekonomi terdistribusi normal. Hal ini tergambar pada Tabel 3.

Tabel 3 atas menunjukkan bahwa $28.16 \%$ dari skor status sosial ekonomi berada pada kelas interval dengan rerata, $39.81 \%$ berada di bawah kelas interval nilai rerata dan $2,04 \%$ berada di atas kelas rerata. Gambaran distribusi frekuensi skor status sosial dapat dilihat pada grafik histogram pada Gambar 2.

Tabel 3. Distribusi Frekuensi Skor Pemberian Status Sosial Ekonomi

\begin{tabular}{|c|c|c|c|c|}
\hline $\begin{array}{c}\text { Kelas } \\
\text { interval }\end{array}$ & Fo & \% fo & Fk & \% fk \\
\hline $10,00-13,27$ & 14 & 13.59 & 14 & 13.59 \\
\hline $13,28-16,55$ & 27 & 26.21 & 41 & 39.81 \\
\hline $16,56-19,83$ & 29 & 28.16 & 70 & 67.96 \\
\hline $19,84-23,11$ & 12 & 11.65 & 82 & 79.61 \\
\hline $23,12-26,39$ & 10 & 9.71 & 92 & 89.32 \\
\hline $26,40-29,67$ & 7 & 6.80 & 99 & 96.12 \\
\hline $29,68-32,95$ & 3 & 2.91 & 102 & 99.03 \\
\hline $32,96-36,23$ & 1 & 0.97 & 103 & 100.00 \\
\hline Jumlah & 103 & $\mathbf{1 0 0 , 0 0}$ & & \\
\hline
\end{tabular}

\section{Lingkungan Kampus Teknik Otomotif Fakultas Teknik UNP}

Data yang diperoleh meliputi skor terendah 58 dan skor tertinggi 93. Hasil pengolahan data diperoleh skor rata-rata (mean) sebesar 77.43, modus (mode) sebesar 82, median sebesar 78 dan simpangan baku (standar deviation) sebesar 7,83. Harga skor rata-rata, modus dan median tidak jauh berbeda dan tidak melebihi satu simpangan baku, ini berarti bahwa distribusi lingkungan kampus terdistribuai normal. Gambaran distribusi frekuensi skor lingkungan kampus digambarkan pada Tabel 4

Tabel 4. Distribusi Frekuensi Skor Lingkungan Kampus

\begin{tabular}{|c|c|c|c|c|}
\hline $\begin{array}{c}\text { Kelas } \\
\text { interval }\end{array}$ & Fo & \% fo & Fk & \% fk \\
\hline $58,00-62,58$ & 4 & 3.88 & 4 & 3.88 \\
\hline $62,59-67,17$ & 6 & 5.83 & 10 & 9.71 \\
\hline $67,18-71,76$ & 16 & 15.53 & 26 & 25.24 \\
\hline $71,77-76,35$ & 20 & 19.42 & 46 & 44.66 \\
\hline $76,36-80,94$ & 20 & 19.42 & 66 & 64.08 \\
\hline $80,95-85,53$ & 18 & 17.48 & 84 & 81.55 \\
\hline $85,54-90,12$ & 16 & 15.53 & 100 & 97.09 \\
\hline $90,13-94,71$ & 3 & 2.91 & 103 & 100.00 \\
\hline Jumlah & 103 & $\mathbf{1 0 0 , 0 0}$ & & \\
\hline
\end{tabular}

Data tabel 4 menunjukkan bahwa $19.42 \%$ dari skor lingkungan kampus berada pada kelas interval skor rata-rata, $44.66 \%$ berada di bawah kelas interval skor rata-rata dan $35.92 \%$. Berikut grafik histogram Lingkungan Kampus. 


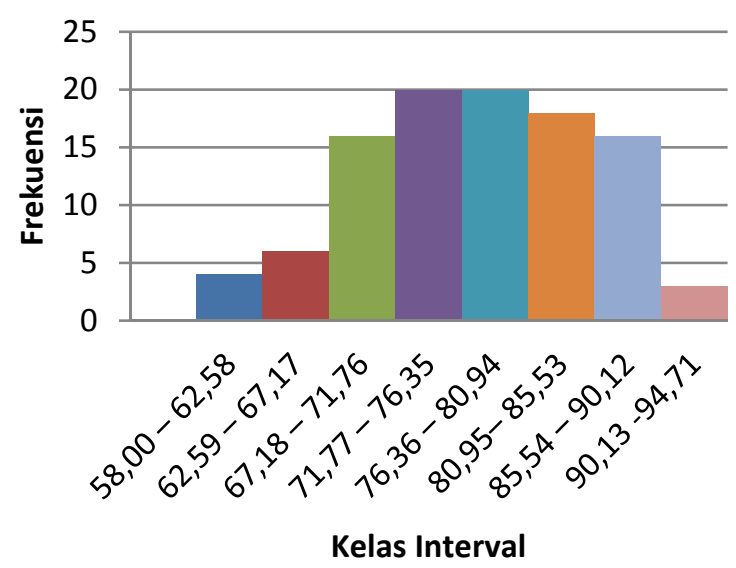

Gambar 3. Grafik histogram Lingkungan Kampus

\section{Uji Normalitas}

Uji normalitas menggunakan tes Kolmogrof Smirnov (Tes K-S), dengan menetapkan taraf signifikan $5 \%$ atau $\alpha=0,05$. Data berdistribusi normal jika taraf signifikan (Asymp.Sig) $>0,05$, hasil pengujian data normalitas dijabarkan pada tabel 5

Tabel 5. Hasil Uji Normalitas dengan Test Kolmogrov Smirnov

\begin{tabular}{|l|c|c|c|c|}
\hline \multicolumn{1}{|c|}{ Variabel } & KS & $\begin{array}{c}\text { Asymp } \\
\text { Sig }\end{array}$ & $\begin{array}{c}\text { Pengu } \\
\text { jian }\end{array}$ & Ket \\
\hline $\begin{array}{l}\text { Status sosial } \\
\text { ekonomi }\end{array}$ & 1,571 & 0,014 & 0,05 & $\begin{array}{c}\text { Tidak } \\
\text { Norm } \\
\text { al }\end{array}$ \\
\hline $\begin{array}{l}\text { Lingkungan } \\
\text { kampus }\end{array}$ & 0,599 & 0.866 & 0,05 & $\begin{array}{c}\text { Norm } \\
\text { al }\end{array}$ \\
\hline $\begin{array}{l}\text { Indeks } \\
\text { prestasi } \\
\text { kumulatif }\end{array}$ & 0,625 & 0.829 & 0,05 & $\begin{array}{c}\text { Norm } \\
\text { al }\end{array}$ \\
\hline
\end{tabular}

Hasil perhitungan normalitas variabel status sosial ekonomi tidak berdistribusi normal. Sedangkan lingkungan kampus dan Indeks prestasi kumulatif berdistribusi normal. Hal ini terlihat dari nilai Asymp Sig pada tabel lebih besar dari 0,05 dan berada di atas kelas skor rata-rata. Gambaran grafik histogram Lingkungan Kampus dapat dilihat pada gambar 3.

\section{E. Uji Linearitas}

Kriteria pengujian linearitas sebagai berikut:

1. Jika nilai Sig $>0,05$ berarti hubungan antara variabel independen dengan dependen adalah linier.

2. Jika nilai $\operatorname{Sig}<0,05$ berarti hubungan antara variabel independen dengan dependen tidak linier

Tabel 6. Hasil Uji Linearitas Variabel Sosial Ekonomi terhadap IPK

\begin{tabular}{|c|r|r|r|r|c|}
\hline Sumber & \multicolumn{1}{|c|}{$\begin{array}{c}\text { Jumlah } \\
\text { Kuadrat }\end{array}$} & dk & RJK & F & p \\
\hline Deviasi & 2.547 & 21 & .121 & $\begin{array}{r}1.28 \\
9\end{array}$ & 0.208 \\
\hline $\begin{array}{c}\text { Dalam } \\
\text { kelompok }\end{array}$ & 7.525 & 80 & .094 & & \\
\hline Total & 10.343 & 102 & & & \\
\hline
\end{tabular}

Tabel 6 memberikan gambaran bahwa nilai signifikan sebesar 0,208 . Sehingga hubungan antara Sosial Ekonomi terhadap IPK terdapat hubugan yang linear.

Tabel 7. Hasil Uji Linearitas Variabel Lingkungan kampus terhadap IPK.

\begin{tabular}{|c|r|r|c|c|c|}
\hline Sumber & $\begin{array}{c}\text { Jumlah } \\
\text { Kuadrat }\end{array}$ & \multicolumn{1}{c|}{$\mathrm{dk}$} & $\mathrm{RJK}$ & $\mathrm{F}$ & $\mathrm{p}$ \\
\hline Deviasi & 2.812 & 30 & .094 & .887 & .634 \\
\hline $\begin{array}{c}\text { Dalam } \\
\text { kelompok }\end{array}$ & 7.502 & 71 & .106 & & \\
\hline Total & 10.343 & 102 & & & \\
\hline
\end{tabular}

Pada tabel 7 nilai signifikan Lingkungan kampus terhadap IPK didapatkan sebesar 0,634. Maka dapat disimpulkan bahwa antara Lingkungan kampus terhadap IPK terdapat hubungan yang linear.

\section{F. Analisis Regresi sederhana}

Hasil analisis regresi sederhana dengan menggunakan SPSS 20.0 For Windows. Hasil analisis regresi sederhana adalah sebagai berikut.

Tabel 8. Hasil analisis regresi sederhana (Sosial Ekonomi-IPK)

\begin{tabular}{|l|r|r|r|r|r|}
\hline \multirow{2}{*}{ Model } & \multicolumn{3}{|c|}{ Coefficients $^{\mathrm{a}}$} \\
& \multicolumn{1}{|c|}{$\begin{array}{c}\text { Standardi } \\
\text { zed } \\
\text { Coeftardized } \\
\text { Coefficie } \\
\text { nts }\end{array}$} & & \\
\cline { 2 - 4 } & $\mathrm{B}$ & $\begin{array}{c}\text { Std. } \\
\text { Error }\end{array}$ & Beta & $\mathrm{t}$ & Sig. \\
\hline 1 (Constant) & 3.164 & .114 & & 27.6 & .000 \\
Status & & & & 50 & \\
sosial & -.010 & .006 & -.162 & 1.64 & .102 \\
ekonomi & & & 9 & \\
\hline
\end{tabular}


Tabel 8 memberikan gambaran bahwa status sosial ekonomi mempunyai pengaruh yang tidak signifikan terhadap indeks prestasi kumulatif mahasiswa. Berdasarkan tabel di atas, maka diperoleh persamaan garis regresi, dengan nilai koefisien regresi bernilai negatif sebesar 0.010 . maka dapat disimpulkan bahwa jika status sosial ekonomi meningkat satu satuan maka nilai Indeks prestasi kumulatif akan menurun 0,010 satuan.

Hasil analisis regresi sederhana menunjukkan bahwa nilai koefisien kolerasi status sosial ekonomi terhadap IPK sebesar 0.162, maka dinyatakan bahwa terdapat pengaruh yang positif status sosial ekonomi terhadap peningkatan indeks prestasi kumulatif mahasiswa Jurusan Teknik Otomotif Fakultas Teknik UNP. Sesuai data sampel $(\mathrm{N}=103) \mathrm{r}$ tabel sebesar 0,195, bila status sosial ekonomi semakin baik maka akan menurunkan indeks prestasi kumulatif mahasiswa Jurusan Teknik Otomotif Fakultas Teknik UNP dan sebaliknya, jadi dapat dikatakan bahwa pengaruh antara status sosial ekonomi terhadap indeks prestasi kumulatif tersebut adalah tidak searah.

Tabel 9. Hasil regresi sederhana (Lingkungan Kampus-IPK)

\begin{tabular}{|c|c|c|c|c|c|}
\hline \multirow[b]{2}{*}{ Model } & \multicolumn{2}{|c|}{$\begin{array}{l}\text { Unstandardized } \\
\text { Coefficients }\end{array}$} & \multirow{2}{*}{$\begin{array}{c}\text { Standardized } \\
\text { Coefficients } \\
\text { Beta }\end{array}$} & \multirow[b]{2}{*}{$\mathrm{t}$} & \multirow[b]{2}{*}{ Sig. } \\
\hline & B & $\begin{array}{l}\text { Std. } \\
\text { Error }\end{array}$ & & & \\
\hline $1 \quad$ (Constant) & 2.814 & .314 & & $\begin{array}{r}8.9 \\
52\end{array}$ & .000 \\
\hline $\begin{array}{l}\text { Lingkungan } \\
\text { kampus }\end{array}$ & .002 & .004 & .054 & $\begin{array}{r}.53 \\
9\end{array}$ & .591 \\
\hline
\end{tabular}

a. Dependent Variable: Indeks prestasi kumulatif

Hasil analisis menunjukkan bahwa koefisien kolerasi lingkungan kampus terhadap IPK sebesar 0.054. Dapat disimpulkan bahwa tidak terdapat pengaruh yang positif antara lingkungan kampus terhadap IPK mahasiswa. Jika kondisi lingkungan bagus dan baik, maka akan tidak meningkatkan indeks prestasi kumulatif mahasiswa Jurusan Teknik Otomotif Fakultas Teknik UNP. Sesuai data sampel $(\mathrm{N}=103) \mathrm{r}$ tabel sebesar 0,195. Jadi dapat dikatakan bahwa pengaruh antara lingkungan kampus dengan Indeks prestasi kumulatif adalah searah. Variabel lingkungan kampus memiliki pengaruh terhadap Indeks prestasi kumulatif sebesar $0,3 \%$ sedangkan $99,7 \%$ ditentukan oleh variabel lain yang tidak teliti.

Pengujian signifikansi bertujuan untuk mengetahui keberartian variabel lingkungan kampus terhadap indeks prestasi kumulatif berpengaruh posistif terhadap indeks prestasi kumulatif. Uji sigifikansi menggunakan uji t. Hasil uji t diperoleh thitung sebesar 0,539, dengan $t$ tabel sebesar 1.65978 pada taraf signifikasi $5 \%$, maka t hitung lebih kecil dari $t$ tabel (1.65978) atau $p$ (0.591) sehingga lingkungan kampus mempunyai pengaruh yang tidak signifikan terhadap indeks prestasi kumulatif mahasiswa Jurusan Teknik Otomotif Fakultas Teknik UNP.

Tabel 10. Hasil Analisis Regresi Sederhana Status Sosial Ekonomi dan Lingkungan kampus terhadap IPK mahasiswa.

\begin{tabular}{|l|r|r|r|r|r|}
\hline \multirow{2}{*}{ Model } & \multicolumn{2}{|c|}{$\begin{array}{c}\text { Unstandardized } \\
\text { Coefficients }\end{array}$} & $\begin{array}{c}\text { Standardized } \\
\text { Coefficients }\end{array}$ & & \\
\cline { 2 - 5 } & \multicolumn{1}{c|}{$\mathrm{B}$} & Std. Error & \multicolumn{1}{c|}{ Beta } & \multicolumn{1}{c|}{$\mathrm{t}$} & Sig. \\
\hline 1 (Constant) & 2.931 & .318 & & 9.204 & .000 \\
$\begin{array}{l}\text { Status sosial } \\
\text { ekonomi }\end{array}$ & -.010 & .006 & -.173 & -1.739 & .085 \\
$\begin{array}{l}\text { Lingkungan } \\
\text { kampus }\end{array}$ & .003 & .004 & .078 & .782 & .436 \\
\hline
\end{tabular}

a. Dependent Variable: Indeks prestasi kumulatif

Tabel 10, menunjukkan bahwa koefisien kolerasi Status Sosial Ekonomi dan Lingkungan kampus terhadap IPK sebesar 0.179, Koefisien kolerasi diatas menunjukkan adanya hubungan positif, sehingga dapat diketahui bahwa terdapat kontribusi yang positif antara status sosial ekonomi dan lingkungan kampus semakin tinggi maka akan meningkatkan indeks prestasi kumulatif mahasiswa Jurusan Teknik Otomotif Fakultas Teknik UNP. Sesuai data sampel $(N=103) r$ tabel sebesar 0,195 , bila status sosial ekonomi dan lingkungan kampus semakin baik maka akan meningkatkan Indeks prestasi kumulatif. Sehingga dapat disimpulkan, kontribusi antara status sosial ekonomi dan lingkungan kampus dengan Indeks prestasi kumulatif tersebut adalah searah.

Nilai koefisien determinasi Status Sosial Ekonomi dan Lingkungan kampus terhadap IPK sebesar 0.179. Hal ini menunjukkan bahwa variabel status sosial ekonomi dan lingkungan kampus berpengaruh terhadap indeks prestasi kumulatif sebesar $3,2 \%$ sedangkan $96,8 \%$ dipengaruhi oleh variabel lain yang tidak teliti.

Pengujian signifikansi dimaksudkan untuk melihat nilai keberartian variabel status sosial ekonomi dan lingkungan kampus secara bersamasama terhadap indeks prestasi kumulatif mahasiswa Jurusan Teknik Otomotif Fakultas Teknik UNP berkontribusi posistif. Berdasarkan hasil uji F, diperoleh F hitung sebesar 1,661. Nilai F tabel sebesar 3,08 pada taraf signifikansi 0.195. 
Dapat disimpulkan bahwa nilai $\mathrm{F}$ hitung lebih kecil dari $F$ tabel (3.08) dengan $p$ (0.195), sehingga Status Sosial Ekonomi dan Lingkungan Kampus mempunyai pengaruh yang tidak signifikan terhadap Indeks Prestasi Kumulatif.

\section{KESIMPULAN}

Status Sosial Ekonomi berpengaruh tidak signifikan terhadap Indeks Prestasi Kumulatif mahasiswa. Lingkungan Kampus berpengaruh tidak signifikan terhadap Indeks Prestasi Kumulatif mahasiswa. Status Sosial Ekonomi dan Lingkungan Kampus berpengaruh terhadap Indeks Prestasi Kumulatif mahasiswa

\section{DAfTAR PUSTAKa}

[1] Nasional, U.-U. S. (2003). Paten No. No. 20 Tahun 2003. Indonesia.

[2] Hamalik, O. (2008). Perencanaan Pengajaran Berdasarkan Pendekatan Sistem. Jakarta: Bumi Aksara.

[3] Saputra, H. D. (2018). Pengaruh Motivasi Terhadap Hasil Belajar Siswa SMK. INVOTEK: Jurnal Inovasi Vokasional dan Teknologi, 25-30.

[4] Saputra, H. D. (2018). Development of WebBased Learning Media in Vocational Secondary School. VOLT: jurnal ilmiah Pendidikan teknik elektro.

[5] Sudjana, N. (2010). Penilaian Hasil Proses Belajar Mengajar. Bandung: PT. Remaja Rosdakarya.

[6] UNP, P. K. (2017).

[7] Dalyono. (2012). Psikologi Pendidikan. Jakarta: Bumi Aksara.

[8] Sugihartono, d. (2015). Psikologi Pendidikan. Yogyakarta: UNY Press
[9] Soekanto, S. (2007). Sosiologi Suatu Pengantar. Jakarta: Rajawali Press.

[10] Slameto. (2010). Belajar dan Faktor-Faktor yang Mempengaruhinya. Jakarta: PT. Rineka Cipta.

[11] Yusuf. (2011). Motivasi Dalam Belajar. Jakarta: P2LPTK.

[12] Sugiyono. (2014). Metode Penelitian Pendidikan ( Pendekatan Kuantitatif, Kualitatif, dan R \& D). Bandung: Alfabeta.

[13] Arikunto, S. (2010). Prosedur Penelitian (Suatu Pendekatan Praktek). Jakarta: PT. Rineka Cipta.

\section{Biodata Penulis}

Dedi Setiawan, lahir 24 Maret 1987. Sarjana Pendidikan Teknik Otomotif FT UNP 2010. Tahun 2014 menyeleseikan Program Magister Pendidikan Teknologi dan Kejuruan pada Pascasarjana FT UNP. Tahun 2017- Sekarang diangkat menjadi Staf pengajar di jurusan Teknik Otomotif FT UNP

Hendra Dani Saputra, lahir 24 Februari 1988. Menyeleseikan program S1 di Jurusan Pendidikan Teknik Otomotif FT UNP tahun 2012. Tahun 2016 menyeleseikan Program Magister Pendidikan Teknologi dan Kejuruan pada program Pascasarjana FT UNP. Staf pengajar di jurusan Teknik Otomotif FT UNP sejak tahun 2017sekarang.

M.Nasir, lahir 17 Maret 1959. Sarjana pendidikan pada IKIP Padang. Menamatkan Magister Pendidikan Teknologi dan Kejuruan UNP. Staf pengajar di jurusan Teknik Otomotif FT UNP sejak tahun 1990- sekarang 